\title{
Maps and Monsters in Medieval England
}

Asa Simon Mittman 


\title{
STUdies IN MEDIEVAL History AND CulTure
}

\author{
Edited by \\ Francis G. Gentry \\ Professor of German \\ Pennsylvania State University
}

A Routledge Series 


\title{
Studies in Medieval History and Culture
}

\author{
FranCIS G. GENTRY, General Editor
}

LITERARY HYBRIDS

Crossdressing, Shapeshifting, and Indeterminacy

in Medieval and Modern French Narrative

Erika E. Hess

THE KInG's Two MAPS

Cartography and Culture in Thirteenth-Century

England

Daniel Birkholz

Pestilence in Medieval and Early

Modern English Literature

Bryon Lee Grigsby

RACE AND ETHNicity IN ANGLO-SAXON

LITERATURE

Stephen J. Harris

AsPeCTS OF LOVE IN JOHN GOWER'S

CONFESSIO AMANTIS

Ellen Shaw Bakalian

The Medieval Tradition of Thebes

History and Narrative in the OF Roman de

Thèbes, Boccaccio, Chaucer, and Lydgate

Dominique Battles

Worlds MAde Flesh

Reading Medieval Manuscript Culture

Lauryn S. Mayer

EMPOWERING COLLABORATIONS

Writing Partnerships between Religious Women and Scribes in the Middle Ages

Kimberly M. Benedict

The Water Supply System of Siena, Italy The Medieval Roots of the Modern Networked City

Michael P. Kucher

The Epistemology of the Monstrous IN THE Middle Ages

Lisa Verner
Desiring TRUTH

The Process of Judgment in Fourteenth-

Century Art and Literature

Jeremy Lowe

The Preaching Fox

Festive Subversion in the Plays of the Wakefield

Master

Warren Edminster

Non-Native SOURCES FOR THE

SCANDINAVIAN KINGS' SAGaS

Paul A. White

Kingship, ConQuest, AND PATRIA

Literary and Cultural Identities in Medieval

French and Welsh Arthurian Romance

Kristen Lee Over

Saracens and the Making OF English

IDENTITY

The Auchinleck Manuscript

Siobhain Bly Calkin

Traveling Through TeXT

Message and Method in Late Medieval

Pilgrimage Accounts

Elka Weber

BetweEN COURTLY Literature AND

Al-ANDALUS

Matière d'Orient and the Importance of Spain in the Romances of the Twelfth-Century Writer

Chrétien de Troyes

Michelle Reichert

Maps ANd Monsters in Medieval

ENGLAND

Asa Simon Mittman 


\section{MAPS AND MONSTERS IN Medieval ENGLAND}

Asa Simon Mittman

Routledge

New York \& London 
Published in 2006 by

Routledge

Taylor \& Francis Group

270 Madison Avenue

New York, NY 10016
Published in Great Britain by

Routledge

Taylor \& Francis Group

2 Park Square

Milton Park, Abingdon

Oxon OX14 4RN

(C) 2006 by Taylor \& Francis Group, LLC

Routledge is an imprint of Taylor \& Francis Group

Printed in the United States of America on acid-free paper

10988766543321

International Standard Book Number-10: 0-415-97613-8 (Hardcover)

International Standard Book Number-13: 978-0-415-97613-8 (Hardcover)

No part of this book may be reprinted, reproduced, transmitted, or utilized in any form by any electronic, mechanical, or other means, now known or hereafter invented, including photocopying, microfilming, and recording, or in any information storage or retrieval system, without written permission from the publishers.

Trademark Notice: Product or corporate names may be trademarks or registered trademarks, and are used only for identification and explanation without intent to infringe.

\section{Library of Congress Cataloging-in-Publication Data}

Catalog record is available from the Library of Congress

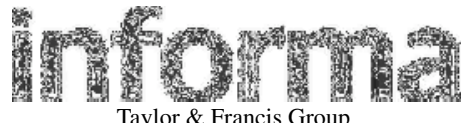

Taylor \& Francis Group is the Academic Division of Informa plc.
Visit the Taylor \& Francis Web site at http://www.taylorandfrancis.com

and the Routledge Web site at http://www.routledge-ny.com 
For Michele-

My world has more than enough monsters, but only one angel. 



\section{Contents}

List of Figures $\quad$ ix

Acknowledgments $\quad$ xix

Introduction

Medieval English Manuscripts, Maps and Monsters: A User's Guide 1

Part One: Mapping the Outer Edges of the World 9

Chapter One

Mythical Origins $\quad 11$

Chapter Two

Mapping Identity $\quad 27$

Chapter Three

The Monsters on the Edge 45

Part Two: The Marvels of the East over Three Centuries and a Millennium

Chapter Four

The Reality and Persistence of Monsters 63

Chapter Five

Containment and Consumption $\quad 83$

Chapter Six

Monstrous Sin and Salvation 107 
Part Three: Lexical Spaces as Battlegrounds

Chapter Seven

Monstrous Nature

Chapter Eight

The Monster Within

Chapter Nine

Saints in the Margins

Conclusion

Dwelling in the Monster

Notes

Bibliography

Index 


\section{List of Figures}

\section{INTRODUCTION FIGURES}

1. London, British Library, Royal 6. B.viii, f. 1v, Human Initial, Isidore's De Fide.

(By permission of the British Library.)

2. Oxford, Bodleian Library, MS Junius 27, f. 34v,

Monstrous Initial, the Junius Psalter. (By permission of the Bodleian Library, the University of Oxford.)

\section{CHAPTER ONE FIGURES}

1.1. Hereford World Map, Detail of Fauni and Straw Drinkers. (By permission of the Dean and Chapter of Hereford and the Hereford Mappa Mundi Trust.)

1.2. Mercator Projection World Map and Proportional Analysis. (By permission of Daniel Dorling and David Fairbairn, Mapping: Ways of Representing the World,

Pearson Education Limited.)

1.3. London, British Library, Cotton Julius D.vii, f. 46r, John of Wallingford Map.

(By permission of the British Library.)

1.4. Oxford, St. John's College Library 17, f. 6r, T-O Map. (By permission of the President and Scholars of Saint John Baptist College in the University of Oxford.) 
1.5. London, British Library, Cotton Vitellius A.xii,

f. 64r, T-O Map. (By permission of the British Library.)

1.6. Hereford World Map, Detail of Judgment.

(By permission of the Dean and Chapter

of Hereford and the Hereford Mappa Mundi Trust.)

1.7. Ebstorf World Map, Detail of Monstrous Races.

(By permission of the British Library.)

\section{CHAPTER TWO FIGURES}

2.1. Hereford World Map. (By permission of the Dean and Chapter of Hereford and the Hereford Mappa Mundi Trust.)

2.2. The National Atlas of the United States, p. 329, World Around the United States Map.

2.3. London, British Library, Royal 1. E.vii, f. 1v, Creator with Compass. (By permission of the British Library.)

2.4. London, British Library Add. 28681, f. 9r, the Psalter Map. (By permission of the British Library.)

2.5. Hereford World Map, Marvelous Races and Monsters Circled. (By permission of the Dean and Chapter of Hereford and the Hereford Mappa Mundi Trust.)

2.6. Ebstorf World Map, Detail of Jerusalem. (By permission of the British Library.)

\section{CHAPTER THREE FIGURES}

3.1. Hereford World Map, Detail of Gigantes and Eden. (By permission of the Dean and Chapter of Hereford and the Hereford Mappa Mundi Trust.)

3.2. Cambridge, Corpus Christi College Library, MS 66, p. 2, Sawley Abbey Map. (By permission of the Master and Fellows of Corpus Christi College, Cambridge.) 
3.3. The Hague, Koninklijke Bibliotheek, MS 76.F.5, f. 1r, the Hague Map of Jerusalem. (By permission of The Hague, Koninklijke Bibliotheek.)

3.4. Hereford World Map, Detail of Marsok. (By permission of the Dean and Chapter of Hereford and the Hereford Mappa Mundi Trust.)

3.5. Hereford World Map, Detail of Choolissime and Wall of Gog and Magog. (By permission of the Dean and Chapter of Hereford and the Hereford Mappa Mundi Trust.)

3.6. Hereford World Map, Detail of the Island of Terraconta. (By permission of the Dean and Chapter of Hereford and the Hereford Mappa Mundi Trust.)

\section{CHAPTER FOUR FIGURES}

4.1. London, British Library, Cotton Claudius B.iv, f. 13r, Giants, the Hexateuch. (By permission of the British Library.)

4.2. British Library, Cotton Nero D.iv, f. 25v, Saint Matthew Author Portrait, the Lindisfarne Gospels. (By permission of the British Library.)

4.3. London, British Library, Cotton Vitellius A.xv, f. 101v, Two-Faced Man, Marvels of the East. (From The Electronic Beowulf, edited by Kevin Kiernan, and used with permission of the British Library Board.)

4.4. London, British Library, Cotton Tiberius B.v, f. 81r, Two-Faced Man, Marvels of the East. (By permission of the British Library.)

4.5. Oxford, Bodleian Library, MS Bodley 614, f. 40r, Two-Faced Man, Marvels of the East. (By permission of the Bodleian Library, the University of Oxford.)

\section{CHAPTER FIVE FIGURES}

5.1. London, British Library, Cotton Claudius B.iv, f. 6r, Adam Names the Animals, the Hexateuch. (By permission of the British Library.) 
5.2. London, British Library, Cotton Vitellius A. xv, f. 102v, Blemmye, Marvels of the East. (From The Electronic Beowulf, edited by Kevin Kiernan, and used with permission of the British Library Board.)

5.3. London, British Library, B.v Tiberius B.v, f. 82r, Blemmye, Marvels of the East.

(By permission of the British Library.)

5.4. Oxford, Bodleian Library, MS Bodley 614, f. 40-41r, Enemies and Blemmye, Marvels of the East. (By permission of the Bodleian Library, the University of Oxford.)

5.5. London, British Library, Add. 62925, f. 87v, Blemmye, Rutland Psalter. (By permission of the British Library.)

5.6. London, British Library, Royal 13. B.viii,f. 30v, Deformed Man, Gerald of Wales's Topography of Ireland. (By permission of the British Library.)

5.7. Hereford World Map, Detail of Sciopod. (By permission of the Dean and Chapter of Hereford and the Hereford Mappa Mundi Trust.)

5.8. Oxford, Bodleian Library, MS Bodley 614, f. 50r, Sciopod, Marvels of the East. (By permission of the Bodleian Library, the University of Oxford.)

5.9. Hereford World Map, Detail of Cannibalistic Essedones. (By permission of the Dean and Chapter of Hereford and the Hereford Mappa Mundi Trust.)

5.10. London, British Library, Cotton Claudius B.iv, f. 24v, Battle against Sodom and Gomorrah, the Hexateuch. (By permission of the British Library.)

5.11. Oxford, Bodleian Library, MS Bodley 614, f. 38v, Homodubi, Cynocephalus and Ants as Big as Dogs, Marvels of the East. (By permission of the Bodleian Library, the University of Oxford.) 
5.12. London, British Library, Cotton Tiberius B.v, f. 83v, Donestre and Pantoii, Marvels of the East. (By permission of the British Library.)

5.13. London, British Library, Cotton Tiberius B.v, f. 81v, Enemies, Marvels of the East. (By permission of the British Library.)

5.14. London, British Library, Cotton Vitellius A.xv, f. 103v, Donestre, Marvels of the East. (From The Electronic Beowulf, edited by Kevin Kiernan, and used with permission of the British Library Board.)

\section{CHAPTER SIX FIGURES}

6.1. London, British Library, Harley 5, f. 4r, Manuscript Repair in Law Code. (By permission of the British Library.)

\section{CHAPTER SEVEN FIGURES}

7.1. Paris, Bibl. Nat., lat. 10861, f. 2r, Monstrous Initial. (By permission of Bibliothèque nationale de France.)

7.2. Oxford, Bodleian Library, Auct. E. inf. 1, f. 2r, Beatus Vir Initial with David Writing and Playing the Harp. (By permission of the Bodleian Library, the University of Oxford.)

7.3. Oxford, Bodleian Library, MS Junius 27, f. 20r, Monstrous Initial, the Junius Psalter. (By permission of the Bodleian Library, the University of Oxford.)

7.4. Oxford, Bodleian Library, MS Junius 27, f. 13v, Monstrous Initial, the Junius Psalter. (By permission of the Bodleian Library, the University of Oxford.)

7.5. Cambridge, University Library MS Ff. I. 23, f. 40v, Monstrous Initial, the Winchcombe Psalter. (By permission of the Syndics of Cambridge University Library.) 
7.6. Cambridge, University Library MS Ff. I. 23, f. 10r, Lamb Initial, the Winchcombe Psalter. (By permission of the Syndics of Cambridge University Library.)

7.7. Cambridge, University Library MS Ff. I. 23, f. 13v, Contorted Human Initial, the Winchcombe Psalter. (By permission of the Syndics of Cambridge University Library.)

7.8. Cambridge, University Library MS Ff. I. 23, f. 43v, Foliate Initial, the Winchcombe Psalter. (By permission of the Syndics of Cambridge University Library.)

7.9. Cambridge, University Library MS Ff. I. 23, f. 44v, Monstrous Initial, the Winchcombe Psalter. (By permission of the Syndics of Cambridge University Library.)

7.10. Cambridge, University Library MS Ff. I. 23, f. 195v, Christ Trampling the Beasts, the Winchcombe Psalter. (By permission of the Syndics of Cambridge University Library.)

7.11. Ruthwell Cross, Christ and the Beasts Panel. (By permission of Alexander M. Bruce.)

7.12. Cambridge, Trinity College MS R. 3. 30, f. 9r, Initial with Swirling Combat and Struggle, Lucan's Pharsalia. (By permission of the Master and Fellows of Trinity College Cambridge.)

7.13. Cambridge, Trinity College MS R. 3. 30, f. 54r, Initial with Man and Beast Trapped in Foliage, Lucan's Pharsalia. (By permission of the Master and Fellows of Trinity College Cambridge.)

7.14. Cambridge, Trinity College MS R. 3. 30, f. 35r, Initial with Fighting Dragons, Lucan's Pharsalia. (By permission of the Master and Fellows of Trinity College Cambridge.)

7.15. Oxford, Bodley MS Auct. E. inf. 1, f. 214v, Dragon Initial, Bible. (By permission of the Bodleian Library, the University of Oxford.) 
7.16. London, British Library, Royal 1. B. xi, f. 72r,

Dragon Initial, Luke Incipit, Gospel Book.

(By permission of the British Library.)

7.17. London, British Library, Royal 1. B. xi, f. 116v, Lamb and Beasts Initial, John Incipit, Gospel Book.

(By permission of the British Library.)

\section{CHAPTER EIGHT FIGURES}

8.1. London, British Library, Royal 1. B.xi, f. 2v, Initial with Man Struggling against Dragon, Jerome’s Prologue, Gospel Book. (By permission of the British Library.)

8.2. London, British Library, Harley 603, f. 22r, Elves Shooting Man. (By permission of the British Library.)

8.3. Cambridge, Trinity College MS O. 2. 51, f. 2r, Initial with Lion and Portrait, Priscian's Grammar. (By permission of the Master and Fellows of Trinity College Cambridge.)

8.4. Cambridge, Trinity College MS O. 2. 51, f. 9r, Initial with Dragon, Lion and Portrait, Priscian's Grammar. (By permission of the Master and Fellows of Trinity College Cambridge.)

8.5. Cambridge, Trinity College MS O. 2. 51, f. 21r, Initial with Dragon, Monk and Grammatica, Priscian's Grammar. (By permission of the Master and Fellows of Trinity College Cambridge.)

8.6. Cambridge, Trinity College MS O. 2. 51, f. 26r, Initial with Priscian (?), Monk and Grammatica, Priscian's Grammar. (By permission of the Master and Fellows of Trinity College Cambridge.)

8.7. Cambridge, Trinity College MS O. 2. 51, f. 34r, Initial with Dragon and Man Intertwined, Priscian's Grammar. (By permission of the Master and Fellows of Trinity College Cambridge.) 
8.8. Cambridge, Trinity College MS O. 2. 51, f. 46r, Initial with Dragon Biting Man, Priscian's Grammar. (By permission of the Master and Fellows of Trinity College Cambridge.)

8.9. Cambridge, Trinity College MS O. 2. 51, f. 59r, Initial with Dragon and Man Battling, Priscian's Grammar. (By permission of the Master and Fellows of Trinity College Cambridge.)

8.10. Cambridge, Trinity College MS O. 2. 51, f. 74r, Initial with Dragon and Man Battling, Priscian's Grammar. (By permission of the Master and Fellows of Trinity College Cambridge.)

8.11. Cambridge, Trinity College MS O. 2. 51, f. 81v, Initial with Man Gaining Upper Hand, Priscian's Grammar. (By permission of the Master and Fellows of Trinity College Cambridge.)

8.12. Cambridge, Trinity College MS O. 2. 51, f. 90r, Initial with Man Attacked by Green Man (?), Priscian's Grammar. (By permission of the Master and Fellows of Trinity College Cambridge.)

8.13. Cambridge, Trinity College MS O. 2. 51, f. 96r, Initial with Dragon Dominant, Priscian's Grammar. (By permission of the Master and Fellows of Trinity College Cambridge.)

8.14. Cambridge, Trinity College MS O. 2. 51, f. 111v, Initial with Man Defeating Dragon while Transforming, Priscian's Grammar. (By permission of the Master and Fellows of Trinity College Cambridge.)

8.15. Cambridge, Trinity College MS O. 2. 51, f. 116v, Initial with Dragon, Priscian's Grammar. (By permission of the Master and Fellows of Trinity College Cambridge.)

8.16. Cambrai, Médiathèque municipale, MS 559, f. 40v, Initial with Dragon Biting Man. (By permission of Cambrai, Médiathèque municipale.) 
8.17. Cambridge, Trinity College MS O. 2. 51, f. 139r, Initial with Dragon, Priscian's Grammar. (By permission of the Master and Fellows of Trinity College Cambridge.)

8.18. Cambridge, Trinity College MS O. 2. 51, f. 139r, Detail of Lower Margin, Sketch of Dragon Head Conjoined to Human Head, Priscian's Grammar. (By permission of the Master and Fellows of Trinity College Cambridge.)

\section{CHAPTER NINE FIGURES}

9.1. London, British Library, Arundel 16, f. 1, Universal Initial, Osbern's Life of Saint Dunstan. (By permission of the British Library.)

9.2. London, British Library, Arundel 16, f. 2, Author Portrait with Censing Acolyte and Beasts, Osbern's Life of Saint Dunstan. (By permission of the British Library.)

9.3. London, British Library, Royal 10. A.xiii, f. 2r, Dunstan Writing, Commentary on the Rule of Saint Benedict. (By permission of the British Library.)

9.4. Dublin, Trinity College Library, A. I. 6, f. 53v, Initial of Tongue-Tied Man, the Book of Kells. (By permission Trinity College, Dublin.)

9.5. Dublin, Trinity College Library, A. I. 6, f. 12r, Initial of Saint Matthew, Argumentum of Matthew, the Book of Kells. (By permission Trinity College, Dublin.)

9.6. Oxford, Bodley MS Tanner 10, f. 115v, Initials of Men and Beasts, Bede's Ecclesiastical History. (By permission of the Bodleian Library, the University of Oxford.)

9.7. Cambridge, Corpus Christi College Library MS 41, Initial $Đ$ with Dragons, Bede's Ecclesiastical History. (By permission of the Master and Fellows of Corpus Christi College, Cambridge.) 
9.8. Cambridge, Corpus Christi College Library MS 41, p. 268, Initial $Đ$ with Dragons, Bede’s Ecclesiastical History. (By permission of the Master and Fellows of Corpus Christi College, Cambridge.)

9.9. Cambridge, Corpus Christi College Library MS 41, p. 410, Initial Đ with Dragons and Crucifixion, Bede's Ecclesiastical History. (By permission of the Master and Fellows of Corpus Christi College, Cambridge.)

9.10. London, British Library, Royal 1. B. xi, f. 5r, Tangled Monstrous Initial, Letter of Eusebius, Gospel Book. (By permission of the British Library.)

\section{CONCLUSION FIGURES}

1. London, British Library, Cotton Claudius B.iv, f. 14r, Noah's Ark, the Hexateuch. (By permission of the British Library.)

2. The Bayeux Tapestry, the English Landing in Normandy. (By permission of Erich Lessing/Art Resource, NY.) 


\section{Acknowledgments}

This project was advised with the greatest care, devotion and indeed affection by George Brown, Milly Budny, Scott Bukatman and Suzanne Lewis. These four have all offered me tremendous support which has stretched beyond my years at Stanford. I would like to particularly thank Suzanne, who has been a constant friend and counselor, always there to buoy my spirits, renew my energy with a loan from her limitless supply and offer sage advice that I have generally had the good sense to take. There are brilliant scholars and there are caring people. I have had the rare fortune to be helped by those who are both.

Thanks must be extended to my two editors, Max Novick and Frank Gentry. While I was fretting over whether or not my book would find a home, Max appeared from out of the ether and offered it one. Frank then took great care in reading multiple drafts, answering all my queries and concerns and always assuring me with, "don't worry-I still like it."

I would also like to thank my family and friends for their endless encouragement. Particularly, I want to thank my parents-my mother, whose life serves as an example to everyone she knows, proving that people not only can, but should and must follow their dreams, and my father, inseparable from her since high school, who only knows how to do things fully and completely, who is invariably right, who slipped into libraries to help me with this book at vital moments and who is one of the few truly good people on this earth.

And, of course, Michele, my wonderful wife, my best friend, my angel, with whom I have crisscrossed the country and the globe, and without whom I wouldn't have written a word. For everything, thank you. 

Introduction

\section{Medieval English Manuscripts, Maps and Monsters: A User's Guide}

The first folio of an Anglo-Saxon manuscript of Isidore's popular De Fide opens with a penned initial 'S' composed of two figures. ' (Fig. 1) The top curve of the letter is formed by a tonsured monk holding a cross-staff, who gestures to his eye with the long fingers of his oversized hand, his gaze fixed on the text he helps to form. The momentum of his body, emphasized by a line running along his back from his head to his feet, carries him forward, tumbling, toward his text. The untonsured figure below gestures with an

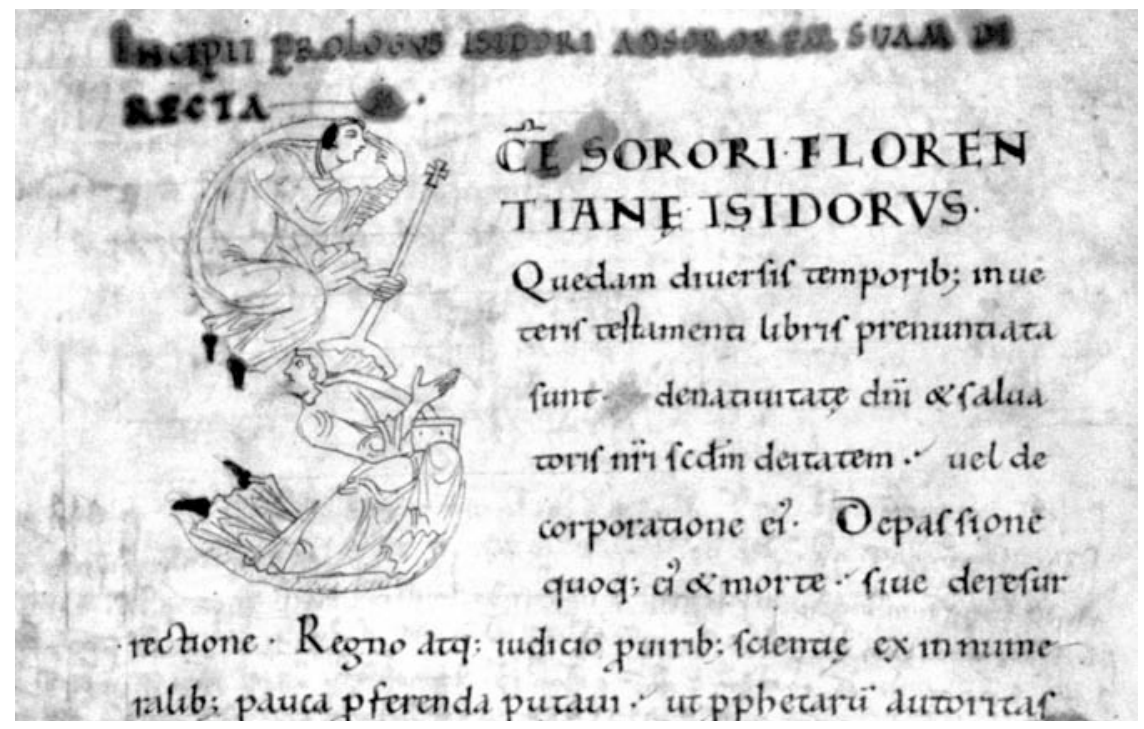

Figure 1. London, British Library, Royal 6. B.viii, f. 1v, Human Initial, Isidore’s De Fide. (By permission of the British Library.) 
open hand toward the script. With a swathe of his robe, he holds a booklikely this manuscript. The lower figure swirls upward, again in the direction of the text block. For the elite, educated Anglo-Saxon viewer, the message would have been clear: "Look closely!" the top figure silently shouts; "at this!" adds his companion.

This image, like many others produced in Anglo-Saxon England, aims to teach the reader how to read both texts and images. These processes, unlike our modern approaches to reading, involved a slow, meditative ingestion and rumination in order to draw out various levels of meaning in the text. ${ }^{2}$ Drawing on the Kosher laws in Leviticus for a metaphor, this process is described by many medieval authors as ruminatio, that is rumination, literally chewing over and over as a cow does with her cud. ${ }^{3}$ The Venerable Bede, an inexhaustible source of observations about early medieval England, uses the same metaphor in his account of the first poet of the English vernacular. The illiterate cowherd Cædmon, having seen a miraculous vision, produced his Hymn. He is then presented with "the course of sacred history" in order that he may produce further poetry: "He turned all which he was able to learn by listening and memorizing-just like a clean animal chewing its cud-into the sweetest song." "'This metaphor, more resonant in an agrarian culture than in our own, not only implies careful consideration, but also suggests the inherent indigestibility of the unprocessed text or image. In this climate, works were designed to sustain the inevitable ruminatio. Hence, any text or image that yields all its meaning after a cursory first glance would likely have been considered inadequate.

The value of close reading was not only conveyed by images of pious clergymen. The metaphor of ruminatio was also enacted through images of monsters, which are found throughout the period gnawing on the texts they help to form. The violent, gnashing beasts of the fabulous Junius Psalter, for example, frequently lash out with sharp fangs at the sacred text before them. ${ }^{5}$ (Fig. 2) Since the Book of Psalms was the very centerpiece of monastic devotion and contemplation, these monsters, these literal embodiments of rumination, are not as out of place as they might first seem.

The present viewer is thus required to associate these monsters, living in the margins of the text, with the pious monks by whom they were painted. If this at first might seem incongruous, or even improper, a brief comparison of the beast from the Junius Psalter and the monastic figure from the manuscript of Isidore's De Fide reveals their close functional and formal affinities. Both lunge forward, swirling toward their texts. Both stare with large eyes at the letters before them. And, beyond these compositional similarities, both are bent and distorted, their bodies twisted to form the first letters of their texts. 


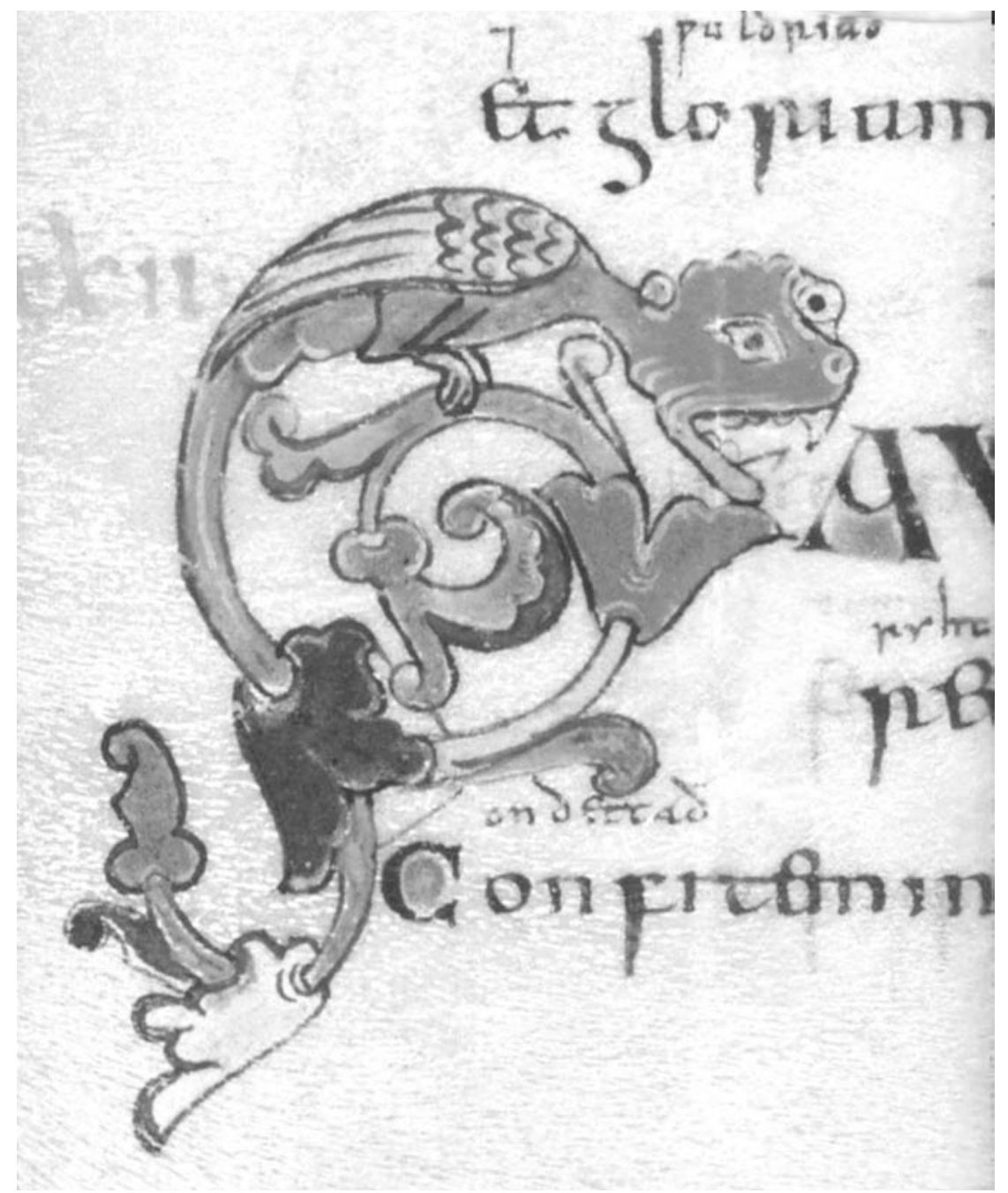

Figure 2. Oxford, Bodleian Library, MS Junius 27, f. 34v, Monstrous Initial, the Junius Psalter. (By permission of the Bodleian Library, the University of Oxford.)

Whereas the monk may encourage us to pay close attention with a milder air, the fang-toothed, bug-eyed monster nonetheless serves as an exhortation of sorts, driving us with its own furious energy toward the psalm before it.

Why were manuscripts worth such attention to medieval readers and, by implication, why are they now worth such close attention by art historians? The Liber scintillarum, a florilegium collected by Defensor which was 
translated into Old English and circulated throughout England, contains a passage by Isidore-the same versatile seventh-century encyclopedist and theologian who penned the De Fide - that informs us that "he who wishes to be with God eternally ought to pray frequently and to read frequently; for when we pray we speak with God, but when we read God speaks with us." 6 In a monastic context, a life focused solely and intently on God, reading manuscripts was a primary means of access to the spiritual world and, at least in this passage, takes precedence over individual prayer. A bilingual AngloSaxon manuscript of The Rule of Saint Benedict, written in the tenth century, tells its readers:

But for those who would rush to the perfection of the way of life, there are the teachings of the Holy Fathers, the observance of which leads a man to the height of perfection. For what page or what speech of the divinely authored books of the Old and New Testaments is not a most lawful rule for human life? Or what book of the Holy Catholic Fathers does not echo how we may come by a straight path to our Creator?

This passage is provided in the original Latin and followed by an Old English translation, in order that the instructions not be misunderstood. ${ }^{8}$ Although Benedict does not mention images in this passage, elsewhere in his Rule, he discusses the virtues of the "labor of the hands," and makes allowances for craftsmen to practice their trades, as long as they may remain humble while doing so. ${ }^{9}$ These brief yet meaningful comments can enable us to understand the production of innumerable illuminated manuscripts, created within an ascetic monastic context for a hyper-consciously contemplative audience. They were vital sites of connection between an earthbound reader and his heavenly aspirations, and as such could command nearly limitless attention by their creators and readers. They now serve as rewarding sites for the extended contemplation of modern viewers wishing to understand the works that now stand before them.

Who were the Anglo-Saxons who created and consumed the medieval books under discussion? In their writings from Bede onward, the Anglo-Saxons represent themselves as Roman Christians. However, it must be noted that they were living, writing and creating a culture far from Rome and Jerusalem, the sites that would have been considered most sacred and important to their spiritual well-being. This self-imposed exile from all that was central to Christian belief caused an anxiety to arise about their place on the earth, which was in turn viewed as a reflection of their place within God's divine plan. This may account for the unusually high number of world 
maps-indeed, maps of any and all kinds-surviving from medieval England. These maps, like our own modern maps, reveal more about their creators than they do about the regions they cover. They therefore command — and would have received-extended rumination.

Although medieval England may well have been a period "notable more for its discontinuities" than its cohesion, there are a few cultural threads that run throughout the period, binding it together even if only loosely. ${ }^{10}$ These ideas appear in both the art and literature of the Anglo-Saxons and Anglo-Normans, and I will treat these forms of cultural expression together, as they were produced and experienced. Several of the images to be discussed appear in manuscripts also containing relevant poetic texts, the most notable being London, British Library, Cotton Vitellius A.xv, which contains an illuminated encyclopedia of monstrous races known as the Marvels of the East as well as the only surviving medieval copy of Beowulf, which pits its eponymous hero against the terrifying, homophagic Grendel and his monstrous mother. ${ }^{11}$ These works were seen as sufficiently interconnected to bind them together in a single manuscript; both then and now, a reading of one helps to inform a reading of the other.

Of course, much of the art produced in this period was explicitly Christian, with doctrinal and didactic emphases on Gospels and Psalters, on images of Christ and the saints. ${ }^{12}$ But what are we to make of the many images that are not overtly or even indirectly devotional? How can we come to terms with the overwhelming array of monsters that lurk at the edges of images and often force their way into the center? These monsters, halfhuman hybrids and bristling dragons were just as essential as images of God and his heavenly hosts for the medieval viewer, whose universal spectrum was broad enough to contain at one end holy perfection and at the other the most wretched and abject, the vile and the absolutely evil. Medieval English viewers would likely have located themselves somewhere between these two extremes, and the lower end of the scale was no less important than the higher end in this process of identity formation. Many cultural groups have sought to define themselves through "an ongoing process of dependent differentiation," establishing themselves in relation to their Others, but for the Anglo-Saxons, this "definition by means of difference" was particularly crucial. ${ }^{13}$ In this way, as Michael Camille argues, "the centre is . . dependent upon the margins for its continued existence." 14

The Anglo-Saxons had many genuine Others with which to compare themselves - the painted Picts to the north, the Celts to the west and of course, the Vikings and Danes, who periodically landed unannounced for plunder or trade. When the Normans arrived, this remained the case. 
Nonetheless, living in self-perceived exile from Continental Europe, these groups were compelled to surround themselves with images of even more disparate Others, monsters that, through their extreme outlandishness, cast their creators as paragons of normality. For the sake of this study, I wish to define "monster" broadly. This term seems, often, to be used as a catch-all phrase which stands in for "everything else." Once proper people, plants, animals, divine and demonic beings have been accounted for, what remains are the oddities of creation, which I would describe as the monsters. They are often the in-between (such as half-human hybrids) or somewhat magical (fire-breathing or dream-controlling), beings somehow, in some way outside of the ordinary. I will expand on these issues and definitions throughout. ${ }^{15}$

In the chapters which follow, I examine a number of images appearing in a variety of contexts. Part One deals with medieval maps and geographical texts. These works, and the monsters they contain, not only reflected AngloSaxon views; they also helped to shape them. Part Two focuses on the semihuman, composite monstrous races of the Marvels of the East. These wondrous beings were called into existence in order to provide a basis of comparison through which their creators might exercise and exorcize their anxieties about their identities as Anglo-Saxons and as human beings. Part Three covers monster-inhabited initials, concentrating on the fluidity of the boundary separating men from beasts.

\section{PROBLEMS OF SOURCES AND HISTORICAL DEFINITION}

Vast amounts of material culture have been lost from the medieval period. C. R. Dodwell enumerates art's many enemies, medieval and modern: grave robbers, fire, reconstruction of churches, reclaiming of precious metals and gems, tithings and Danegelds, raiders, and so on. ${ }^{16}$ Anglo-Saxon themselves often wrote about these losses. ${ }^{17}$ So much has been lost to the caprices of time and nature that Dodwell rightly raises the possibility that "we have [no works] that the Anglo-Saxons themselves would have considered impressive from the later and longer Christian period." 18 George Henderson acknowledges that the volume of loss makes the rules of production, consumption and interpretation difficult to define in this period. ${ }^{19}$ On account of the great losses, I have cast a wider net than the traditional historical boundaries might allow. Strictly speaking, the Anglo-Saxon period begins with the entrance of the Angles, Saxons and Jutes into England, some time in the fifth century and ends on October Fourteenth, 1066, at the moment Harold is killed. The initial boundary is uncertain, since all accounts were written much later and the endpoint, while extremely precise in its chronology, still 
does not provide the sort of closure we might desire. Although the crown had passed hands, it has been widely acknowledged that Insular culture was slow to react. Archeological, stylistic, linguistic, ecclesiastical and political history all show surprising continuity in the century or two following $1066 .{ }^{20}$

On account of the many continuities, and the great losses, I believe that it is not merely helpful but indeed necessary for a study of this sort, which seeks to understand broad cultural notions, to examine all available evidence at its disposal in order to gain a more complete understanding of the complex works of art and literature under consideration. Certain themes were of enduring importance, relevant in the sixth century when Gildas wrote his De excidio Britonum (The Fall of Britain) and still relevant seven centuries later when of Richard of Haldingham created the Hereford Mappamundi. ${ }^{21}$ The discussion which follows will be primarily focused on the tenth, eleventh and twelfth centuries. This period begins with the era of the Benedictine reform, which was accompanied by an increase in manuscript production, and carries through the years following the Conquest. I will make two chronological exceptions: I will look ahead to the thirteenth century's efflorescence of great world maps-which I will present as the outgrowth of a centuries-old tradition of geographical thought—and I will gaze back to select texts and images created in the early Anglo-Saxon or Insular period, but housed, copied, read and appreciated throughout the centuries under discussion. By reaching across the boundaries traditionally separating Early from High and Anglo-Saxon from Anglo-Norman, we may gain a clearer understanding of the issues of marginality and monstrosity-issues which are themselves frequently characterized by a refusal to obey just such rules and boundaries. 